The Canadian Mineralogist

Vol. 41, pp. 61-70 (2003)

\title{
THE CRYSTAL CHEMISTRY OF NEPHELINE
}

\author{
KimberLy T. TAIT, Elena SOKOLOVA AND FRANK C. HAWTHORNE ${ }^{\S}$ \\ Department of Geological Sciences, University of Manitoba, Winnipeg, Manitoba R3T 2N2 Canada
}

ALEXANDER P. KHOMYAKOV

Institute of Mineralogy, Geochemistry and Crystal Chemistry of Rare Elements, Moscow 121357, Russia

\begin{abstract}
The crystal structures of three nepheline samples, (1) $\mathrm{K}_{1.91} \mathrm{Na}_{6.04} \mathrm{Si}_{8.15} \mathrm{Al}_{7.72} \mathrm{Fe}^{3+}{ }_{0.10} \mathrm{O}_{32}, a$ 9.9995(6), $c$ 8.384(2) $\AA, P 6_{3}, Z$ $=1, D_{\mathrm{x}}=2.673 \mathrm{~g} \mathrm{~cm}^{-3}$, from the Khibina-Lovozero complex, Kola Peninsula, Russia, (2) $\mathrm{K}_{1.60} \mathrm{Na}_{6.21} \mathrm{Ca}_{0.08} \mathrm{Si}_{8.44} \mathrm{Al}_{7.43} \mathrm{O}_{32}, a$ 9.985(1), c 8.372(1) Å, $P 6_{3}, Z=1, D_{x} 2.660 \mathrm{~g} / \mathrm{cm}^{3}$, from Bancroft, Ontario, Canada, and (3) $\mathrm{K}_{1.76} \mathrm{Na}_{5.86} \mathrm{Ca}_{0.13} \mathrm{Si}_{8.12} \mathrm{Al}_{7.84} \mathrm{Fe}^{3+}{ }_{0.04}$ $\mathrm{O}_{32}, a 9.9979(6), c 8.3852(2), P 6_{3}, Z=1, D_{x} 2.654 \mathrm{~g} / \mathrm{cm}^{3}$, from Monte Somma, Italy, have been refined to $R_{1}$ indices of $1.8,2.7$ and $1.7 \%$ using 1273,1191 and 1364 unique observed $\left(\left|F_{\mathrm{o}}\right|>4 \sigma F\right)$ reflections collected with a single-crystal diffractometer and $\mathrm{MoK} \alpha \mathrm{X}$-radiation. No superstructure reflections were observed. Viewed down [001], the aluminosilicate tetrahedra occur at the vertices of a $6_{3}$ net in which there are two distinct types of six-membered rings of tetrahedra: one quarter are nearly regular hexagonal rings centered on $(0,0, z)$, whereas the other three-quarters are flattened hexagonal rings centered on $01 / 2 z$. In both rings, the tetrahedra have the sequence $u d u d u d$, and linkage up and down $c$ forms a four-connected three-dimensional framework. The $A$ site is located in the channel along $00 z$ and is [9]-coordinated by oxygen atoms between 2.97 and $3.04 \AA ;<A-O>=2.999$, 3.009 and $3.008 \AA$ for samples 1, 2 and 3, respectively. The $A$ site is fully occupied by $\mathrm{K}$ in nepheline (1), and it is partly occupied by $\mathrm{K}(0.80$ and 0.88$)$ in samples (2) and (3). The $B$ site occurs in the channels at $01 / 2 z$ and is [8]-coordinated by oxygen atoms between 2.48 and $2.79 \AA ;\langle B-\mathrm{O}>=2.633,2.632$ and $2.627 \AA$, respectively. The $B$ site is occupied mainly by Na [with minor Ca in nepheline (3)]. For all three samples, $\mathrm{Si}$ and $\mathrm{Al}$ are highly ordered over the $T$ sites of the framework: $T(1,4)=\mathrm{Al},\langle T(1)-\mathrm{O}\rangle=$ $1.731,1.723$ and $1.732,<T(4)-\mathrm{O}>=1.736,1.728$ and $1.734 ; T(2,3)=\mathrm{Si},\langle T(2)-\mathrm{O}>=1.606,1.603$ and $1.605,\langle T(3)-\mathrm{O}>=1.616$, 1.615 and $1.616 \AA$. For the nepheline sample from the Khibina-Lovozero complex, the simplified chemical formula, $\mathrm{K}_{2} \mathrm{Na}_{6} \mathrm{Si}_{8}$ $\mathrm{Al}_{8} \mathrm{O}_{32}$, corresponds to the ideal end-member formula of nepheline with the $A$ site fully occupied by $\mathrm{K}$, the $B$ site fully occupied by $\mathrm{Na}$, and $\mathrm{Si}$ and $\mathrm{Al}$ completely ordered at the $T$ sites. This sample crystallized in a hyperagpaitic rock formed at the last stages of low-temperature pneumatolitic activity. Nepheline (2), also formed in low-temperature pegmatitic environment, shows very high Al-Si order at the $T$ sites. The Monte Somma nepheline is of high-temperature origin. Previous refinements of the structure had indicated a fairly disordered $\mathrm{Al}-\mathrm{Si}$ distribution for it. The present results indicate maximal Al-Si order, in accord with previous ${ }^{29} \mathrm{Si}$ MAS NMR results. Our results suggest that nepheline exhibits maximal Al-Si order irrespective of temperature of origin of the nepheline.
\end{abstract}

Keywords: nepheline, cation ordering, end-member composition, Khibina-Lovozero, Russia, Bancroft, Canada, Monte Somma, Italy.

\section{SOMMAIRE}

Nous avons affiné la structure cristalline de trois échantillons de néphéline, (1) $\mathrm{K}_{1.91} \mathrm{Na}_{6.04} \mathrm{Si}_{8.15} \mathrm{Al}_{7.72} \mathrm{Fe}^{3+}{ }_{0.10} \mathrm{O}_{32}, a$ 9.9995(6), $c 8.384(2) \AA, P 6_{3}, Z=1, D_{\mathrm{x}}=2.673 \mathrm{~g} / \mathrm{cm}^{3}$, provenant du complexe alcalin de Khibina-Lovozero, péninsule de Kola, en Russie, (2) $\mathrm{K}_{1.60} \mathrm{Na}_{6.21} \mathrm{Ca}_{0.08} \mathrm{Si}_{8.44} \mathrm{Al}_{7.43} \mathrm{O}_{32}, a$ 9.985(1), $c$ 8.372(1) $\AA$, $P 6_{3}, Z=1, D_{x} 2.660 \mathrm{~g} / \mathrm{cm}^{3}$, de Bancroft, Ontario, Canada, et (3) $\mathrm{K}_{1.76} \mathrm{Na}_{5.86} \mathrm{Ca}_{0.13} \mathrm{Si}_{8.12} \mathrm{Al}_{7.84} \mathrm{Fe}^{3+}{ }_{0.04} \mathrm{O}_{32}, a$ 9.9979(6), c 8.3852(2), $P 6_{3}, Z=1, D_{x} 2.654 \mathrm{~g} / \mathrm{cm}^{3}$, de Monte Somma, en Italie, jusqu'a'un résidu $R_{1}$ de $1.8,2.7$ et $1.7 \%$ en utilisant 1273, 1191 et 1364 réflexions uniques observées $\left(\left|F_{0}\right|>4 \sigma F\right)$, prélevées avec un diffractomètre à cristal unique et un rayonnement $\operatorname{Mo} K \alpha$. Nous n'avons pas vu de réflexions attribuables à une surstructure. Vus le long de [001], les tétraèdres aluminosilicatés se situent aux noeuds d'un réseau $6_{3}$ dans lequel il y a deux types d'anneaux à six tétraèdres: dans un quart des cas, il s'agit d'anneaux hexagonaux presque réguliers centrés sur $(0,0, z)$, tandis que les autres sont des anneaux hexagonaux aplatis centrés sur $01 / 2 z$. Dans les deux cas, les tétraèdres montrent la séquence $u d u d u d$, et leur articulation le long de l'axe $c$ mène à une trame tridimensionnelle à quatre points de connexion. Le site $A$ est situé dans un canal le long de $00 z$ et montre une coordinence [9] aux atomes d'oxygène à une distance de 2.97 à $3.04 \AA$; $<A-O>=2.999,3.009$ and $3.008 \AA$ pour les échantillons 1,2 et 3, respectivement. Le site $A$ est rempli d'atomes de $\mathrm{K}$ dans l'échantillon (1), et il est partiellement occupé par le potassium (0.80 et 0.88) dans les échantillons (2) et (3). Le site $B$ est situé dans les canaux à $01 \frac{1}{2} z$ et

§ E-mail address: frank_hawthorne@umanitoba.ca 
montre une coordinence [8] avec les atomes d'oxygène à une distance entre 2.48 et $2.79 \AA$; $\langle B-\mathrm{O}>=2.633,2.632$ et $2.627 \AA$, respectivement. Le site $B$ contient surtout des atomes de $\mathrm{Na}$ [avec une proportion mineure de Ca dans l'échantillon (3)]. Dans les trois échantillons, les atomes de $\mathrm{Si}$ et de $\mathrm{Al}$ sont fortement ordonnés parmi les sites $T$ de la trame: $T(1,4)=\mathrm{Al},\langle T(1)-\mathrm{O}\rangle=1.731$, 1.723 et $1.732,\langle T(4)-\mathrm{O}\rangle=1.736,1.728$ et $1.734 ; T(2,3)=\mathrm{Si},\langle T(2)-\mathrm{O}\rangle=1.606,1.603$ et $1.605,\langle T(3)-\mathrm{O}\rangle=1.616,1.615$ et 1.616 Å. Dans le cas de l'échantillon provenant du complexe de Khibina-Lovozero, la formule simplifiée, $\mathrm{K}_{2} \mathrm{Na}_{6} \mathrm{Si}_{8} \mathrm{Al}_{8} \mathrm{O}_{32}$, correspond à celle du pôle idéal de la néphéline ayant le site $A$ complètement rempli d'atomes de $\mathrm{K}$, le site $B$ complètement rempli d'atomes $\mathrm{Na}$, et les atomes $\mathrm{Si}$ et $\mathrm{Al}$ complètement ordonnés sur les sites $T$. Cet échantillon de néphéline a cristallisé dans une pegmatite hyperagpaïtique à un stade ultime d'activité pneumatolitique à faible température. L'échantillon (2), aussi formé à faible température dans un milieu pegmatitique, montre un degré d'ordre Al-Si maximal. La néphéline du Monte Somma a une origine à température plus élevée. Les travaux antérieurs avaient indiqué un degré d'ordre Al-Si passablement désordonné. Nos résultats indiquent un degré d'ordre maximal pour cette composition, ce qui concorde avec les spectres ${ }^{29} \mathrm{Si}$ MAS NMR antérieurs. Nos résultats semblent montrer que la néphéline fait preuve d'un degré d'ordre Al-Si maximal quelle que soit la température de sa cristallisation.

(Traduit par la Rédaction)

Mots-clés: néphéline, mise en ordre des cations, composition du pôle, Khibina-Lovozero, Russie, Bancroft, Canada, Monte Somma, Italie.

\section{INTRODUCTION}

The crystal structure of nepheline was solved by Buerger et al. (1954) and Hahn \& Buerger (1955). Nepheline is a stuffed derivative of tridymite, with an Si:Al ratio of $1: 1$ and a decrease in symmetry from $P 6_{3} /$ $m m c$ in tridymite to $P 6_{3}$ in nepheline. Viewed down [001] (Fig. 1), the nepheline structure consists of aluminosilicate tetrahedra at the vertices of a $6_{3}$ net, with alkali cations in the interstices. There are two types of six-membered rings of tetrahedra that link in the (001) plane to form a sheet (Fig. 1) in which alternate tetrahedra point in different directions along the $c$ axis; these sheets are stacked together along [001] to form a framework. In the (001) projection (Fig. 1), one quarter of the rings, centered on $00 \mathrm{z}$, are nearly regular, and three quarters of the rings, centered on $01 / 2 z$, are strongly distorted. There are two distinct alkali-metal sites: the $A$ site is located in the channel along $00 z$ and is coordinated by nine oxygen atoms, and the $B$ site is located in the channels at $01 \frac{1}{2} z$ and is coordinated by seven or eight oxygen atoms. The conformation adopted by each six-membered ring is due to the adjacent cations in the channels and the reduction in strain obtained when $\mathrm{Si}-$ $\mathrm{O}-\mathrm{Si}$ or $\mathrm{Si}-\mathrm{O}-\mathrm{Al}$ relax to their optimum values (Merlino 1984).

In this paper, we re-examine the structure of nepheline in order to evaluate its long-range order. In particular, we test the hypothesis that the degree of Al$\mathrm{Si}$ order of nepheline varies with environment of formation.

\section{ReVIEW of Previous Work}

The formulae of nepheline crystals for which the crystal structure has been refined are shown in Table 1 . The $A$ site is generally two-thirds occupied by $\mathrm{K}$ and one-third occupied by $\square$ (vacancy), the $B$ site is completely occupied by $\mathrm{Na}$ and minor $\mathrm{Ca}$, and the $\langle A-\mathrm{O}\rangle$ and $\langle B-\mathrm{O}\rangle$ distances are constant in all nepheline structures. The principal features of $\mathrm{Al}-\mathrm{Si}$ ordering in nepheline were described by Dollase \& Peacor (1971) and Dollase \& Thomas (1978). From the data in Table 1, the following pattern of order is apparent: $T(1): \mathrm{Al} \geq \mathrm{Si}$; $T(2): \mathrm{Al}<\mathrm{Si} ; T(3): \mathrm{Al}<\mathrm{Si} ; T(4)$ : $(\mathrm{Al}, \mathrm{Si})$. The $T(1)$ and $T(2)$ cations bond to the $\mathrm{O}(1)$ oxygen that is disordered off the 3-fold axis to accommodate the tilting of the $T(1)$ and $T(2)$ tetrahedra that accompanies framework relaxation and satisfaction of the bond-valence requirements of the cation(s) at the $B$ site. The oxygen atoms $\mathrm{O}(3)$ and $\mathrm{O}(4)$ are bonded to $T(1)$ and $T(2)$, respectively, and shift in response to the disorder of the $\mathrm{O}(1)$ atom. The anisotropic-displacement coefficients of these atoms are largest along the $c$ axis (Dollase 1970). About 1/3 of the $A$ site is usually vacant. The real structure of nepheline involves coupling of $\mathrm{K}-\square$ ordering and oxygen-atom displacement. Nepheline generally shows diffuse superstructure reflections (Sahama 1958, McConnell 1962), with some degree of irrational character. This has been interpreted in terms of domains involving differences in Al-Si ordering (McConnell 1962), $\mathrm{K}-\square$ ordering (Foreman \& Peacor 1970, Merlino 1984) and positional order of the O(1) anion (Parker \& McConnell 1971, Parker 1972).

\section{OCCURRENCE}

During work on the Khibina-Lovozero complex, Kola peninsula, Russia, nepheline of composition close to the end-member, $\mathrm{K}_{2} \mathrm{Na}_{6} \mathrm{Si}_{8} \mathrm{Al}_{8} \mathrm{O}_{32}$, was discovered in a drill core from the Mount Koashva area at Khibina. It occurs in a hydrothermal veinlet cutting ijolite-urtite, in close association with fersmanite and lamprophyllite. Nepheline (2) is also from a low-temperature environment; it occurs in a pegmatite in nepheline syenite near Bancroft, Ontario, Canada. Nepheline (3) is from a hightemperature environment; it occurs in marble blocks in volcanic ejecta at Monte Somma, Mount Vesuvius, 
Italy. The Monte Somma nepheline was studied by Buerger et al. (1954), Hahn \& Buerger (1955) and Sahama (1962), and was previously considered to be fairly disordered from these diffraction studies.

\section{Collection of X-Ray Data}

Two irregular fragments and a sphere (Table 2) were mounted on a Siemens $P 4$ diffractometer equipped with a serial detector and $\mathrm{Mo} K \alpha \mathrm{X}$-radiation. Reflections over the range $9.5<2 \theta<29.5^{\circ}$ were centered, and the unit-cell dimensions were refined by least-squares from the resultant setting angles (Table 2 ). Intensity data were collected in $\theta-2 \theta$ scan mode over three asymmetric units out to a maximum $2 \theta$ value of $\sim 60^{\circ}$. After this, psi-scan data were collected at increments of $5^{\circ}$ for reflections distributed over the complete range of $2 \theta$. An absorption correction, modeling the crystals as triaxial ellipsoids, reduced $R$ (azimuthal) from 2.20 to 2.18 and from
1.54 to 1.13 for nepheline (1) and (2), respectively. An absorption correction for nepheline (3) failed owing to extreme extinction. The crystal was immersed for $3 \mathrm{~h}$ in liquid nitrogen $\left(\mathrm{T}=-180^{\circ} \mathrm{C}\right)$, and all data were recollected. Miscellaneous information for nepheline (3) before immersion is as follows: $a$ 9.9953(7), $c$ 8.3822(12), $R_{1} 12.60, T(1) 1.725, T(2) 1.610, T(3) 1.621, T(4) 1.730$ $\AA$, essentially the same as that measured after immersion in nitrogen. After immersion, an absorption correction, modeling nepheline (3) as a sphere, reduced $R$ (azimuthal) from 1.36 to 1.32. Data were corrected for Lorentz, polarization and background effects, averaged and reduced to structure factors.

Subsequent to the collection of the intensity data, the single-crystal of nepheline (1) was mounted on a $P 4$ diffractometer fitted with a CCD detector and $\operatorname{MoK} \alpha$ $\mathrm{X}$-radiation. The diffraction pattern was very carefully examined for additional reflections using $30 \mathrm{~s}$ frames, but there was no evidence of superlattice reflections.

TABLE 1. CHEMICAL FORMULA, CELL PARAMETERS AND DETAILS OF $A, B$ and $T$ SITES FOR REFINED NEPHELINE AND SYNTHETIC NEPHELINE CRYSTALS

\begin{tabular}{|c|c|c|c|c|c|c|c|}
\hline Formula (apfu) & $a(\AA)$ & $c(\AA)$ & A site & $<A-O>(\AA)$ & $B$ site & $<B-O>(\AA)$ & Ref. \\
\hline \multicolumn{8}{|c|}{ Mineral } \\
\hline $\mathrm{K}_{1.20} \mathrm{Na}_{5.60} \mathrm{Ca}_{0.40}\left(\mathrm{Al}_{7.60} \mathrm{Si}_{8.40}\right) \mathrm{O}_{32}{ }^{*}$ & 10.010 & 8.405 & $\mathrm{~K}_{1.20} \mathrm{Ca}_{0.2} \square_{0.60}$ & 2.96 & $\mathrm{Na}_{5.58} \mathrm{Ca}_{0.18} \square_{0.24}$ & 2.65 & (1) \\
\hline $\mathrm{K}_{1.28} \mathrm{Na}_{5.36} \mathrm{Ca}_{0.28}\left(\mathrm{Al}_{7.92} \mathrm{Si}_{8.08}\right) \mathrm{O}_{32}$ & $10.003(2)$ & $8.381(3)$ & $\mathrm{K}_{1.28} \square_{0.72}$ & $3.017(4)$ & $\mathrm{Na}_{5.36} \mathrm{Ca}_{0.30} \square_{0.20}$ & $2.630(4)$ & (2) \\
\hline $\mathrm{K}_{1.40} \mathrm{Na}_{5.47} \mathrm{Ca}_{0.30}\left(\mathrm{Al}_{7.47} \mathrm{Si}_{8.53}\right) \mathrm{O}_{32}$ & $10.007(7)$ & $8.385(5)$ & $\mathrm{K}_{1.40} \square_{0.60}$ & $3.024(5)$ & $\mathrm{Na}_{5.36} \mathrm{Ca}_{0.30} \square_{0.21}$ & $2.619(5)$ & (3) \\
\hline $\mathrm{K}_{1.32} \mathrm{Na}_{5.64} \mathrm{Ca}_{0.36}\left(\mathrm{Al}_{7.93} \mathrm{Si}_{8.07}\right) \mathrm{O}_{32}{ }^{\star \star}$ & $9.993(2)$ & $8.374(3)$ & $\mathrm{K}_{1.56} \square_{0.44}$ & $3.007(7)$ & $\mathrm{Na}_{5.36} \mathrm{Ca}_{0.30} \square_{0.22}$ & $2.622(5)$ & (4) \\
\hline $\mathrm{K}_{1.60} \mathrm{Na}_{6,21} \mathrm{Ca}_{0.08}\left(\mathrm{Al}_{7.43} \mathrm{Si}_{8.44}\right) \mathrm{O}_{32}$ & $9.985(1)$ & $8.372(1)$ & $\mathrm{K}_{1.60} \mathrm{Ca}_{0.08} \square_{0.32}$ & $3.009(3)$ & $\mathrm{Na}_{6.00}$ & $2.632(8)$ & (5) \\
\hline $\mathrm{K}_{1.76} \mathrm{Na}_{5.86} \mathrm{Ca}_{0.13}\left(\mathrm{Al}_{7.84} \mathrm{Si}_{8.12} \mathrm{Fe}^{3+}{ }_{0.04}\right) \mathrm{O}_{32}$ & $9.9979(6)$ & $8.3852(11)$ & $\mathrm{K}_{1.76} \square_{0.24}$ & $3.008(2)$ & $\mathrm{Na}_{5.86} \mathrm{Ca}_{0.13}$ & $2.627(3)$ & (6) \\
\hline \multicolumn{8}{|c|}{ Synthetic } \\
\hline $\mathrm{K}_{0.24} \mathrm{Na}_{6.00}\left(\mathrm{Al}_{6.24} \mathrm{Si}_{9.76}\right) \mathrm{O}_{32}$ & $9.964(10)$ & $8.360(8)$ & $\mathrm{K}_{0.24} \square_{1.76}$ & 3.020 & $\mathrm{Na}_{6.00}$ & 2.610 & (5) \\
\hline $\mathrm{K}_{0.96} \mathrm{Na}_{6.96}\left(\mathrm{Al}_{7.92} \mathrm{Si}_{8.08}\right) \mathrm{O}_{32}$ & $9.968(3)$ & $8.380(5)$ & $\mathrm{K}_{0.96} \mathrm{Na}_{0.96} \square_{0.08}$ & 3.026 & $\mathrm{Na}_{6}$ & 2.611 & (6) \\
\hline Formula (apfu) & $T(1)$ site & \multicolumn{2}{|c|}{$\begin{array}{l}<T(1)-O>\quad T(2) \text { site } \\
(\AA)\end{array}$} & $\begin{array}{c}<T(2)-O> \\
(\AA)\end{array}$ & $\begin{array}{r}T(3) \text { site } \quad<T(3)-0 \\
(\AA)\end{array}$ & $\begin{array}{c}<T(3)-O> \\
(\AA)\end{array}$ & $\begin{array}{l}<T(4)-O>\text { Ref. } \\
(\AA)\end{array}$ \\
\hline
\end{tabular}

\section{$\mathrm{K}_{1.20} \mathrm{Na}_{5.60} \mathrm{Ca}_{0.40}\left(\mathrm{Al}_{7.60} \mathrm{Si}_{8.40}\right) \mathrm{O}_{32}$ * \\ $\mathrm{K}_{1.28} \mathrm{Na}_{5.36} \mathrm{Ca}_{0.28}\left(\mathrm{Al}_{7.92} \mathrm{Si}_{8.08}\right) \mathrm{O}_{32}$ \\ $\mathrm{K}_{1.40} \mathrm{Na}_{5.47} \mathrm{Ca}_{0.30}\left(\mathrm{Al}_{7.47} \mathrm{Si}_{8.53}\right) \mathrm{O}_{32}$ \\ $\mathrm{K}_{1.32} \mathrm{Na}_{5.64} \mathrm{Ca}_{0.36}\left(\mathrm{Al}_{7.93} \mathrm{Si}_{8.07}\right) \mathrm{O}_{32}{ }^{* *}$ \\ $\mathrm{K}_{1.60} \mathrm{Na}_{6,21} \mathrm{Ca}_{0.08}\left(\mathrm{Al}_{7.43} \mathrm{Si}_{8.44}\right) \mathrm{O}_{32}$ \\ $\mathrm{K}_{1.76} \mathrm{Na}_{5.86} \mathrm{Ca}_{0.13}\left(\mathrm{Al}_{7.84} \mathrm{Si}_{8.12} \mathrm{Fe}^{3+}{ }_{0.04}\right) \mathrm{O}_{32} \mathrm{Al}_{0.99} \mathrm{Si}_{0.01}$

$\mathrm{Al}_{1.0}$
$\mathrm{Al}_{0.51} \mathrm{Si}_{0.49}$
$\mathrm{Al}_{0.60} \mathrm{Si}_{0.40}$
$\mathrm{Al}_{0.70} \mathrm{Si}_{0.30}$
$\mathrm{Al}_{0.97} \mathrm{Si}_{0.03}$
$\mathrm{Al}_{0.99} \mathrm{Si}_{0.01}$

\begin{tabular}{|c|c|c|c|c|c|c|c|}
\hline & Mineral & & & & & & \\
\hline $1.78(2)$ & $\mathrm{Si}_{1.0}$ & $1.64(3)$ & $\mathrm{Si}_{0.53} \mathrm{Al}_{0.47}$ & $1.67(1)$ & $\mathrm{Si}_{0.53} A \mathrm{I}_{0.47}$ & $1.68(2)$ & (1) \\
\hline $1.697(8)$ & $\mathrm{Si}_{0.58} \mathrm{Al}_{0.42}$ & $1.651(8)$ & $\mathrm{Si}_{0.84} \mathrm{Al}_{0.16}$ & $1.628(3)$ & $\mathrm{Al}_{0.73} \mathrm{Si}_{0.27}$ & $1.718(4)$ & (2) \\
\hline $1.693(8)$ & $\mathrm{Si}_{0.77} \mathrm{Al}_{0.23}$ & $1.649(8)$ & $\mathrm{Si}_{0.87} \mathrm{Al}_{0.13}$ & $1.636(5)$ & $\mathrm{Al}_{0.78} \mathrm{Si}_{0.22}$ & $1.712(5)$ & (3) \\
\hline $1.725(24)$ & $\mathrm{Si}_{0.86} \mathrm{Al}_{0.14}$ & $1.642(26)$ & $\mathrm{Si}_{0.92} \mathrm{Al}_{0.08}$ & $1.623(6)$ & $\mathrm{Al}_{0.82} \mathrm{Si}_{0.18}$ & $1.744(6)$ & (4) \\
\hline $1.723(5)$ & $S i_{1.00}$ & $1.603(5)$ & $S i_{1.00}$ & $1.615(4)$ & $\mathrm{Al}_{0.94} \mathrm{Si}_{0.06}$ & $1.728(4)$ & (5) \\
\hline \multirow[t]{2}{*}{$1.732(3)$} & $S i_{1.06}$ & $1.605(3)$ & $\mathrm{Si}_{1.00}$ & $1.616(2)$ & $\mathrm{Al}_{0.98} \mathrm{Si}_{0.01} \mathrm{Fe}^{3+}{ }_{0.01}$ & $1.734(2)$ & (6) \\
\hline & Synthetic & & & & & & \\
\hline $1.691(27)$ & $\mathrm{Si}_{0.60} \mathrm{Al}_{0.40}$ & $1.629(27)$ & $\mathrm{Si}_{0.60} \mathrm{Al}_{0.40}$ & $1.664(14)$ & $\mathrm{Si}_{0.60} \mathrm{Al}_{0.40}$ & $1.667(14)$ & (5) \\
\hline $1.730(6)$ & $S i_{1.00}$ & $1.624(5)$ & $S i_{1.00}$ & $1.621(2)$ & $\mathrm{Al}_{1.00}$ & $1.726(2)$ & $(6$ \\
\hline
\end{tabular}

$\mathrm{K}_{0.24} \mathrm{Na}_{6.00}\left(\mathrm{Al}_{6.24} \mathrm{Si}_{9.76}\right) \mathrm{O}_{32}$

$\mathrm{K}_{0.96} \mathrm{Na}_{6.96}\left(\mathrm{Al}_{7.92} \mathrm{Si}_{8.08}\right) \mathrm{O}_{32}$
$\mathrm{Si}_{0.60} A \mathrm{I}_{0.40}$

$\mathrm{Al}_{1,00}$

(1) Hahn \& Buerger (1955); (2) Simmons \& Peacor (1972); (3) Dollase (1970); (4) Foreman \& Peacor (1970); (5) Dollase \& Thomas (1978); (6) Gregorkiewitz (1984). * This formula, given by Hahn \& Buerger (1955), was not measured for the sample investigated, but was estimated as an average formula from "many chemical analyses". ${ }^{\star \star}$ This formula was taken from Tilley (1954), who analyzed York River nepheline. 


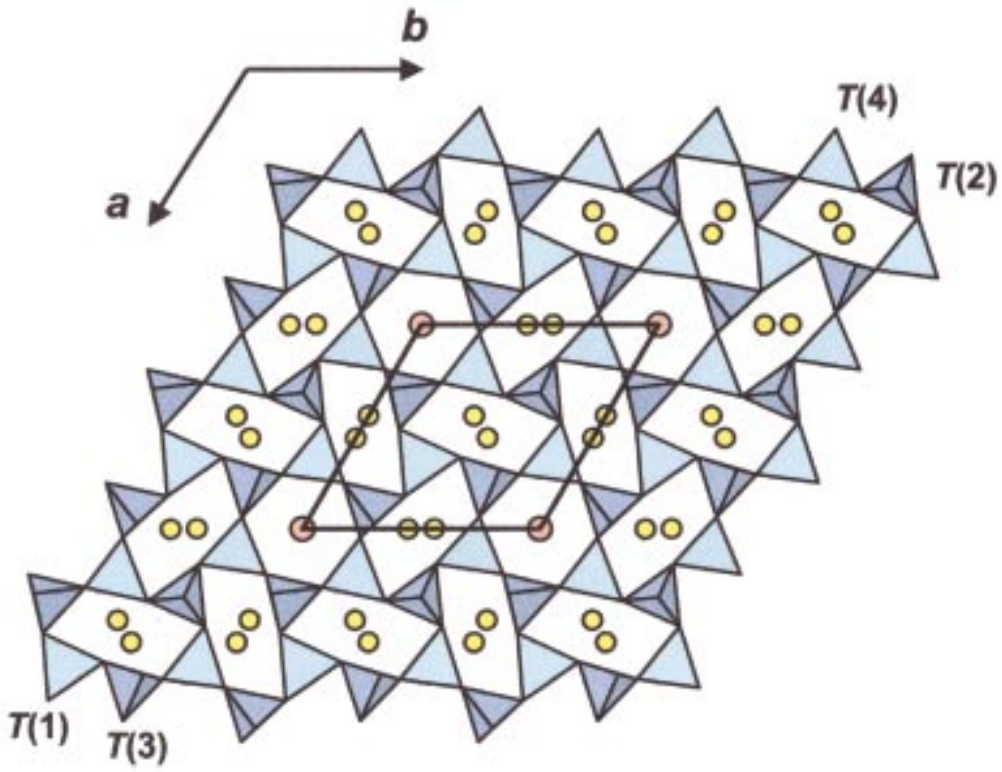

FIG. 1. The crystal structure of the nepheline projected onto (001). The $T(2)$ and $T(3)$ tetrahedra $(\mathrm{Si}>\mathrm{Al})$ are navy blue, the $T(1)$ and $T(4)$ tetrahedra $(\mathrm{Al}>\mathrm{Si})$ are greenish blue, the $K$ sites are shown as orange spheres, and the $N a$ sites, as yellow spheres.

TABLE 2. MISCELLANEOUS CRYSTAL-STRUCTURE REFINEMENT DATA FOR NEPHELINE

\begin{tabular}{|c|c|c|c|}
\hline & (1) & $(2)$ & $(3)$ * \\
\hline$a(\AA)$ & $9.9995(6)$ & $9.985(1)$ & $9.9979(6)$ \\
\hline$c$ & $8.384(2)$ & $8.372(1)$ & $8.3852(11)$ \\
\hline$V\left(\AA^{3}\right)$ & $726.0(2)$ & $723.0(2)$ & $725.9(2)$ \\
\hline Space Group & $P 6_{3}$ & $P 6_{3}$ & $P 6_{3}$ \\
\hline$Z$ & 1 & 1 & 1 \\
\hline Absorption coefficient $\left(\mathrm{mm}^{-1}\right)$ & 1.11 & 1.08 & 1.10 \\
\hline$D\left(\right.$ calc) $\left(\mathrm{g} / \mathrm{cm}^{3}\right)$ & 2.673 & 2.660 & 2.654 \\
\hline$F(000)$ & 640.0 & 635.1 & 636.1 \\
\hline Crystal size $(\mathrm{mm})$ & $0.04 \times 0.14 \times 0.24$ & $0.08 \times 0.08 \times 0.10$ & 0.18, sphere \\
\hline Radiation & MoKa & MoKa & MoKa \\
\hline $2 \theta$ maximum $\left({ }^{\circ}\right)$ & 60.03 & 60.13 & 60.04 \\
\hline$R$ (int) (\%) & 1.8 & 2.7 & 1.7 \\
\hline Reflections collected & 4092 & 4460 & 4451 \\
\hline Unique reflections & 1419 & 1419 & 1419 \\
\hline$F_{0}>4 \sigma F$ & 1273 & 1191 & 1364 \\
\hline Refinement method & \multicolumn{3}{|c|}{ Least-squares on $F^{2}$; fixed weights proportional to $1 / \sigma\left(F_{0}{ }^{2}\right)$} \\
\hline Final $R$ (obs) (\%) & 1.78 & 2.10 & 1.59 \\
\hline$R$ (all data) (\%) & 2.08 & 2.75 & 1.68 \\
\hline$w R_{2}$ & 4.37 & 4.55 & 4.17 \\
\hline GoF & 1.023 & 0.990 & 1.101 \\
\hline
\end{tabular}

* after temperature shock 


\section{Electron-Microprobe AnAlysis}

The crystals used to collect the X-ray intensity data were mounted in a perspex disc, ground, polished and coated with carbon for chemical analysis using a Cameca SX-50 electron microprobe. Ten points were analyzed with the following conditions: excitation voltage: $15 \mathrm{kV}$; specimen current: $20 \mathrm{nA}$; beam size $15 \mu \mathrm{m}$. The following standards and crystals were used $(K \alpha \mathrm{X}$ ray lines): Na: albite, TAP; Al: kyanite, TAP; $\mathrm{Si}, \mathrm{Ca}$ : diopside, PET; K: orthoclase, PET; Fe: arfvedsonite, $\mathrm{LiF}$. The resulting average chemical composition is given in Table 3. The unit formulae (Table 3) were calculated on the basis of 32 oxygen apfu (atoms per formula unit): note that the composition of nepheline (1),

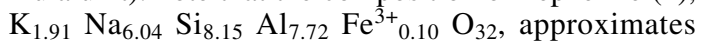
closely to the end-member composition $\mathrm{K}_{2} \mathrm{Na}_{6} \mathrm{Si}_{8} \mathrm{Al}_{8}$ $\mathrm{O}_{32}$.

\section{CRystal-Structure Refinement}

The atom coordinates of nepheline (Foreman \& Peacor 1970) were used as the initial structure model for nepheline (1). The crystal structures of nepheline (13 ) were refined with the SHELXTL 5.1 software (Sheldrick 1997) using scattering factors for neutral atoms from the International Tables for X-ray Crystallography (1992), with the exception of oxygen, for which the ionic scattering curve was used $\left[\mathrm{O}^{2-}\right]$. For nepheline (1), the refinement converged rapidly to an $R$ index of $2.0 \%$ using 1273 unique observed reflections. Large values of the displacement parameters $\left(U_{11}\right.$ and $\left.U_{22}\right)$ for $\mathrm{O}(1)$ indicate that this site is slightly disordered off the 3 -fold axis. Further refinement of the structure with $\mathrm{O}(1)$ displaced off the 3 -fold axis gave an $\mathrm{O}(1)$ site occupancy of $0.331(1)$ and an $R$ index of $1.8 \%$. For nepheline crystals 2 and 3, refinement was initiated with the atom coordinates of nepheline (1) with $\mathrm{O}(1)$ displaced off the 3 -fold axis, resulting in $R_{1}$ indices of 2.1 and $1.6 \%$, respectively. Final atom parameters are given in Table 4, selected interatomic distances and angles are given in Table 5, and bond valences are shown in Table 6. Final observed and calculated structure-factors may be obtained from The Depository of Unpublished Data, CISTI, National Research Council, Ottawa, Ontario K1A 0S2, Canada.

\section{The AL-Si Framework}

There are four unique tetrahedrally coordinated sites in the crystal structure of nepheline, with $\langle T-\mathrm{O}\rangle$ distances of $1.731,1.606,1.617$ and $1.736 \AA$ for nepheline (1) $1.723,1.603,1.615$ and $1.728 \AA$ A for nepheline (2), and 1.732, 1.605, 1.616 and $1.734 \AA$ for nepheline (3). Obviously, there is considerable order of $\mathrm{Al}\left({ }^{[4]} \mathrm{r}=0.39\right.$ $\AA$ ) and $\mathrm{Si}\left({ }^{[4]} \mathrm{r}=0.26 \AA\right.$; values from Shannon 1976) over the $T$ sites. In order to determine site-populations, we need to quantitatively relate the $<T-\mathrm{O}>$ distances to the site occupancies. There is no relation yet developed for the nepheline structures, and hence we will use similar relations in the feldspars of the plagioclase series to examine this issue. Kroll \& Ribbe (1983) showed a stepped linear relation between the grand $\langle T-\mathrm{O}\rangle$ distance and the $<\mathrm{Al} /(\mathrm{Al}+\mathrm{Si})>$ value in plagioclase feldspars. Using the relation for Na-bearing plagioclase feldspars, the grand $\langle T-\mathrm{O}\rangle$ distances of $1.672,1.667$ and $1.672 \AA$ in our three crystals result in $\mathrm{Al} /(\mathrm{Al}+\mathrm{Si})$ ratios of $0.50,0.46$ and 0.50 , in reasonable accord with the observed values of $0.49,0.47$ and 0.49 (treating minor $\mathrm{Fe}^{3+}$ as $\mathrm{Al}$ ). The feldspars thus may be a good analogue for assigning site-occupancies in nepheline. In the structure of ordered anorthite (Wainwright \& Starkey 1971), the $<\mathrm{Si}-\mathrm{O}>$ distances are in the range $1.608-1.617 \AA$ and the $<\mathrm{Al}-\mathrm{O}>$ distances are in the range $1.742-1.755 \AA$. The $\langle T(2)-\mathrm{O}\rangle$ and $\langle T(3)-\mathrm{O}\rangle$ distances in our samples of nepheline are 1.603-1.606 and 1.615-1.616 $\AA$, in the range of $<\mathrm{Si}-\mathrm{O}>$ distances in anorthite, suggesting that $T(2)=T(3)=\mathrm{Si}$ in our material. The $\langle T(1)-\mathrm{O}\rangle$ and $\langle T(4)-\mathrm{O}\rangle$ distances in our samples are $1.723-1.732$ and $1.728-1.736 \AA$, somewhat less than the range of values observed in anorthite $(1.742-1.755 \AA)$. This is in accord with the fact that $\mathrm{Al}$ / $(\mathrm{Al}+\mathrm{Si})$ is less than 0.50 in all three crystals, and hence both $T(1)$ and $T(4)$ cannot be completely occupied by Al. The fact that both $\langle T(1)-\mathrm{O}\rangle$ and $\langle T(4)-\mathrm{O}\rangle$ are less than the $<\mathrm{Al}-\mathrm{O}>$ values in anorthite suggests that both $T(1)$ and $T(4)$ contain $\mathrm{Si}$ in addition to Al. Note that the $T(1)$ and $T(2)$ tetrahedra are involved in the largest $T-\mathrm{O}-T$ angle $\left(155.2-156.9^{\circ}\right.$, Table 5$)$ in the nepheline framework. Larger $T-\mathrm{O}-T$ angles tend to be involved in shorter $T-\mathrm{O}$ distances, perhaps accounting for the fact that $\langle T(2)-\mathrm{O}\rangle$ is less than $\langle T(3)-\mathrm{O}\rangle$, even though both sites are occupied by Si only. By the same token, one would expect $\langle T(1)-\mathrm{O}\rangle$ to be smaller than $<T(4)-\mathrm{O}>$ for the same site-occupancies. Inverting this argument, we conclude that $T(1)$ and $T(4)$ have identical site-occupancies. Final site-populations are given in Table 7.

\section{The InTERStitial Sites}

There are two interstitial sites, $A$ and $B$, in the channels that extend along the $c$ axis (Fig. 1). The $A$ site

\begin{tabular}{|c|c|c|c|c|c|c|c|}
\hline & (1) & $(2)$ & (3) & & (1) & (2) & (3) \\
\hline $\mathrm{Na}_{2} \mathrm{O}$ & 15.99 & 16.51 & 15.67 & $\mathrm{Na}^{+}$ & 6.04 & 6.21 & 5.86 \\
\hline $\mathrm{K}_{2} \mathrm{O}$ & 7.69 & 6.46 & 7.13 & $\mathrm{~K}^{+}$ & 1.91 & 1.60 & 1.76 \\
\hline $\mathrm{CaO}$ & - & 0.39 & 0.62 & $\mathrm{Ca}^{2+}$ & - & 0.08 & 0.13 \\
\hline $\mathrm{Al}_{2} \mathrm{O}_{3}$ & 33.65 & 32.46 & 34.46 & $\Sigma$ & 7.95 & 7.89 & 7.75 \\
\hline $\mathrm{SiO}_{2}$ & 41.83 & 43.49 & 42.09 & & & & \\
\hline $\mathrm{Fe}_{2} \mathrm{O}_{3}$ & 0.69 & 0.01 & 0.28 & $\mathrm{Al}^{3+}$ & 7.72 & 7.43 & 7.84 \\
\hline \multirow[t]{3}{*}{$\Sigma$} & 99.85 & 99.32 & $\overline{100.25}$ & $\mathrm{Si}^{4+}$ & 8.15 & 8.44 & 8.12 \\
\hline & & & & $\mathrm{Fe}^{3+}$ & 0.10 & - & 0.04 \\
\hline & & & & $\Sigma$ & 15.97 & 15.87 & 16.00 \\
\hline
\end{tabular}


occurs on the $6_{3}$ screw axis in the larger channel and is [9]-coordinated. The $B$ site occurs within the smaller channel and is [8]-coordinated. The occupancies were assigned from the results of the electron-microprobe analysis of the crystals and are given in Table 7. The $B$ polyhedra share common trans edges to form zig-zag chains along the $c$ axis (Fig. 2). Three of these chains connect to each other via common vertices [i.e., the oxygen atom $\mathrm{O}(1)]$ to form a continuous framework of $B$ polyhedra. Each $A$ polyhedron connects to six chains of $B$ polyhedra (Fig. 2), sharing common edges with three $B$ polyhedra and common single vertices with three other $B$ polyhedra. The $A$ polyhedra do not link to each other along the channel parallel to the $c$ axis.

As noted in the refinement procedure, the $\mathrm{O}(1)$ anion is disordered off the 3 -fold axis. In order to under-

TABLE 4. ATOM POSITIONS AND DISPLACEMENT PARAMETERS FOR NEPHELINE

\begin{tabular}{|c|c|c|c|c|c|c|c|c|c|c|}
\hline \multicolumn{11}{|c|}{ (1) } \\
\hline & $x$ & $y$ & $z$ & $U_{\text {eq }}$ & $U_{11}$ & $U_{22}$ & $U_{33}$ & $U_{23}$ & $U_{13}$ & $U_{12}$ \\
\hline$A$ & 0 & 0 & $0.01170(1)$ & $0.02164(17)$ & $0.01898(19)$ & $0.01898(19)$ & $0.0270(4)$ & 0 & 0 & $0.00949(9)$ \\
\hline$B$ & $0.99905(7)$ & $0.55466(7)$ & $0.5178(3)$ & $0.02311(19)$ & $0.0311(4)$ & $0.0238(3)$ & $0.0193(3)$ & $0.0010(7)$ & $-0.0013(7)$ & $0.0174(3)$ \\
\hline$T(1)$ & $2 / 3$ & $1 / 3$ & $0.2121(3)$ & $0.01011(24)$ & $0.0096(4)$ & $0.0096(4)$ & $0.0112(6)$ & 0 & 0 & $0.00478(18)$ \\
\hline$T(2)$ & $1 / 3$ & $2 / 3$ & $0.3222(3)$ & $0.01037(22)$ & $0.0101(3)$ & $0.0101(3)$ & $0.0109(6)$ & 0 & 0 & $0.00506(16)$ \\
\hline$T(3)$ & $0.75946(8)$ & $0.66605(8)$ & $0.33229(22)$ & $0.00985(14)$ & $0.0091(3)$ & $0.0096(3)$ & $0.0115(3)$ & $-0.0002(3)$ & $-0.0001(3)$ & $0.0051(2)$ \\
\hline$T(4)$ & $0.09249(8)$ & $0.75965(9)$ & $0.20566(22)$ & $0.00899(16)$ & $0.0077(3)$ & $0.0084(3)$ & $0.0107(4)$ & $-0.0001(3)$ & $0.0001(3)$ & $0.0038(3)$ \\
\hline$O(1)$ & $0.3697(6)$ & $0.696(4)$ & $0.5103(9)$ & $0.027(3)$ & $0.017(3)$ & $0.049(13)$ & $0.0091(14)$ & $0.005(7)$ & $0.002(3)$ & $0.013(4)$ \\
\hline$O(2)$ & $0.71067(12)$ & $0.68560(13)$ & $0.5113(4)$ & $0.02036(23)$ & $0.0170(5)$ & $0.0384(6)$ & $0.0107(5)$ & $-0.0003(10)$ & $-0.0007(8)$ & $0.0176(4)$ \\
\hline$O(3)$ & $1.1728(3)$ & $0.6484(3)$ & $0.2610(4)$ & $0.0274(5)$ & $0.0111(9)$ & $0.0104(9)$ & $0.0618(14)$ & $0.0030(9)$ & $-0.0042(9)$ & $0.0063(7)$ \\
\hline$O(4)$ & $0.6516(3)$ & $0.48999(22)$ & $0.2766(4)$ & $0.0240(4)$ & $0.0140(9)$ & $0.0105(8)$ & $0.0484(12)$ & $-0.0086(8)$ & $-0.0061(8)$ & $0.0075(7)$ \\
\hline$O(5)$ & $0.94000(21)$ & $0.71478(21)$ & $0.3346(3)$ & $0.0136(3)$ & $0.0097(6)$ & $0.0174(7)$ & $0.0133(7)$ & $-0.0014(6)$ & $0.0001(6)$ & $0.0065(6)$ \\
\hline$O(6)$ & $0.73563(21)$ & $0.77827(23)$ & $0.2110(3)$ & $0.0166(4)$ & $0.0211(8)$ & $0.0163(8)$ & $0.0185(8)$ & $0.0041(7)$ & $0.0026(7)$ & $0.0138(7)$ \\
\hline
\end{tabular}

(2)

\begin{tabular}{lccllllllcc}
\hline & $x$ & $y$ & $z$ & $U_{\mathrm{eq}}$ & $U_{11}$ & $U_{22}$ & $U_{33}$ & $U_{23}$ & $U_{13}$ & $U_{12}$ \\
\hline$A$ & 0 & 0 & $0.01170(1)$ & $0.0241(3)$ & $0.0204(3)$ & $0.0204(3)$ & $0.0316(6)$ & 0 & 0 & $0.01019(14)$ \\
$B$ & $0.99813(8)$ & $0.55455(8)$ & $0.5174(5)$ & $0.02352(16)$ & $0.0312(4)$ & $0.0241(4)$ & $0.0204(3)$ & $0.0002(11)$ & $-0.0017(12)$ & $0.0176(3)$ \\
$T(1)$ & $2 / 3$ & $1 / 3$ & $0.2114(5)$ & $0.0119(4)$ & $0.0108(5)$ & $0.0108(5)$ & $0.0142(10)$ & 0 & 0 & $0.0054(3)$ \\
$T(2)$ & $1 / 3$ & $2 / 3$ & $0.3225(5)$ & $0.0118(3)$ & $0.0123(5)$ & $0.0123(5)$ & $0.0110(9)$ & 0 & 0 & $0.00613(23)$ \\
$T(3)$ & $0.75966(12)$ & $0.66575(12)$ & $0.3322(4)$ & $0.01130(20)$ & $0.0107(4)$ & $0.0109(4)$ & $0.0129(5)$ & $0.0003(5)$ & $0.0004(5)$ & $0.0058(4)$ \\
$T(4)$ & $0.09294(12)$ & $0.76047(13)$ & $0.2056(4)$ & $0.01051(22)$ & $0.0082(5)$ & $0.0095(5)$ & $0.0127(6)$ & $-0.0001(5)$ & $0.0001(5)$ & $0.0036(4)$ \\
$O(1)$ & $0.3720(5)$ & $0.694(4)$ & $0.5091(13)$ & $0.035(3)$ & $0.017(3)$ & $0.072(11)$ & $0.012(3)$ & $0.029(6)$ & $0.0070(4)$ & $0.020(5)$ \\
$O(2)$ & $0.71056(14)$ & $0.68338(17)$ & $0.5121(7)$ & $0.0243(3)$ & $0.0187(6)$ & $0.0462(8)$ & $0.0140(4)$ & $0.0030(18)$ & $-0.0012(13)$ & $0.0208(6)$ \\
$O(3)$ & $1.1731(4)$ & $0.6497(4)$ & $0.2621(7)$ & $0.0314(8)$ & $0.0131(13)$ & $0.0119(13)$ & $0.0692(24)$ & $0.0017(13)$ & $-0.0058(14) 0.0064(11)$ \\
$O(4)$ & $0.6516(4)$ & $0.4889(3)$ & $0.2759(6)$ & $0.0263(7)$ & $0.0148(13)$ & $0.0113(12)$ & $0.0541(20)$ & $-0.0078(12)$ & $-0.0083(13)$ & $0.0076(11)$ \\
$O(5)$ & $0.9399(3)$ & $0.7137(3)$ & $0.3328(6)$ & $0.0141(5)$ & $0.0090(8)$ & $0.0178(9)$ & $0.0161(11)$ & $-0.0012(9)$ & $0.0004(9)$ & $0.0072(7)$ \\
$O(6)$ & $0.7341(3)$ & $0.7764(4)$ & $0.2111(6)$ & $0.0188(6)$ & $0.0223(11)$ & $0.0208(11)$ & $0.0202(12)$ & $0.0030(11)$ & $0.0035(10)$ & $0.0159(10)$ \\
\hline
\end{tabular}

(3)

\begin{tabular}{lcccccccccc}
\hline & $x$ & $y$ & $z$ & $U_{\text {eq }}$ & $U_{11}$ & $U_{22}$ & $U_{33}$ & $U_{23}$ & $U_{13}$ & $U_{12}$ \\
\hline$A$ & 0 & 0 & $0.01170(1)$ & $0.02170(19)$ & $0.01841(20)$ & $0.01841(20)$ & $0.0283(4)$ & 0 & 0 & $0.00920(10)$ \\
$B$ & $0.99817(6)$ & $0.55432(6)$ & $0.5179(3)$ & $0.02255(18)$ & $0.0305(3)$ & $0.0230(3)$ & $0.0190(3)$ & $0.0008(5)$ & $-0.0011(5)$ & $0.01703(22)$ \\
$T(1)$ & $2 / 3$ & $1 / 3$ & $0.2118(3)$ & $0.01030(19)$ & $0.0098(3)$ & $0.0098(3)$ & $0.0113(5)$ & 0 & 0 & $0.00491(14)$ \\
$T(2)$ & $1 / 3$ & $2 / 3$ & $0.32226(24)$ & $0.01048(17)$ & $0.01035(23)$ & $0.01035(23)$ & $0.0107(4)$ & 0 & 0 & $0.00517(12)$ \\
$T(3)$ & $0.75948(6)$ & $0.66603(6)$ & $0.33221(19)$ & $0.00994(11)$ & $0.00933(21)$ & $0.00965(21)$ & $0.0117(3)$ & $-0.00061(23$ & $-0.00014(230.00538(17)$ \\
$T(4)$ & $0.09289(7)$ & $0.76022(7)$ & $0.20557(20)$ & $0.00960(14)$ & $0.0081(3)$ & $0.0085(3)$ & $0.0117(3)$ & $-0.0002(3)$ & $0.0003(3)$ & $0.00376(20)$ \\
$O(1)$ & $0.3698(9)$ & $0.7021(19)$ & $0.5099(7)$ & $0.0273(16)$ & $0.027(4)$ & $0.043(8)$ & $0.0088(12)$ & $0.001(4)$ & $-0.001(3)$ & $0.0152(22)$ \\
$O(2)$ & $0.71021(11)$ & $0.68420(13)$ & $0.5111(3)$ & $0.02174(21)$ & $0.0178(4)$ & $0.0416(6)$ & $0.0112(5)$ & $0.0011(9)$ & $0.0009(6)$ & $0.0189(4)$ \\
$O(3)$ & $1.17348(20)$ & $0.64926(21)$ & $0.2616(4)$ & $0.0290(4)$ & $0.0096(7)$ & $0.0124(7)$ & $0.0657(12)$ & $0.0032(7)$ & $-0.0042(7)$ & $0.0060(6)$ \\
$O(4)$ & $0.65115(21)$ & $0.48976(18)$ & $0.2757(3)$ & $0.0251(4)$ & $0.0133(7)$ & $0.0097(6)$ & $0.0531(10)$ & $-0.0083(7)$ & $-0.0061(7)$ & $0.0062(6)$ \\
$O(5)$ & $0.94001(16)$ & $0.71420(17)$ & $0.3341(3)$ & $0.0146(3)$ & $0.0098(5)$ & $0.0189(6)$ & $0.0151(6)$ & $-0.0008(5)$ & $0.0011(5)$ & $0.0073(5)$ \\
$O(6)$ & $0.73421(17)$ & $0.77705(19)$ & $0.2109(3)$ & $0.0167(3)$ & $0.0220(7)$ & $0.0172(6)$ & $0.0175(7)$ & $0.0040(6)$ & $0.0036(6)$ & $0.0147(6)$ \\
\hline
\end{tabular}




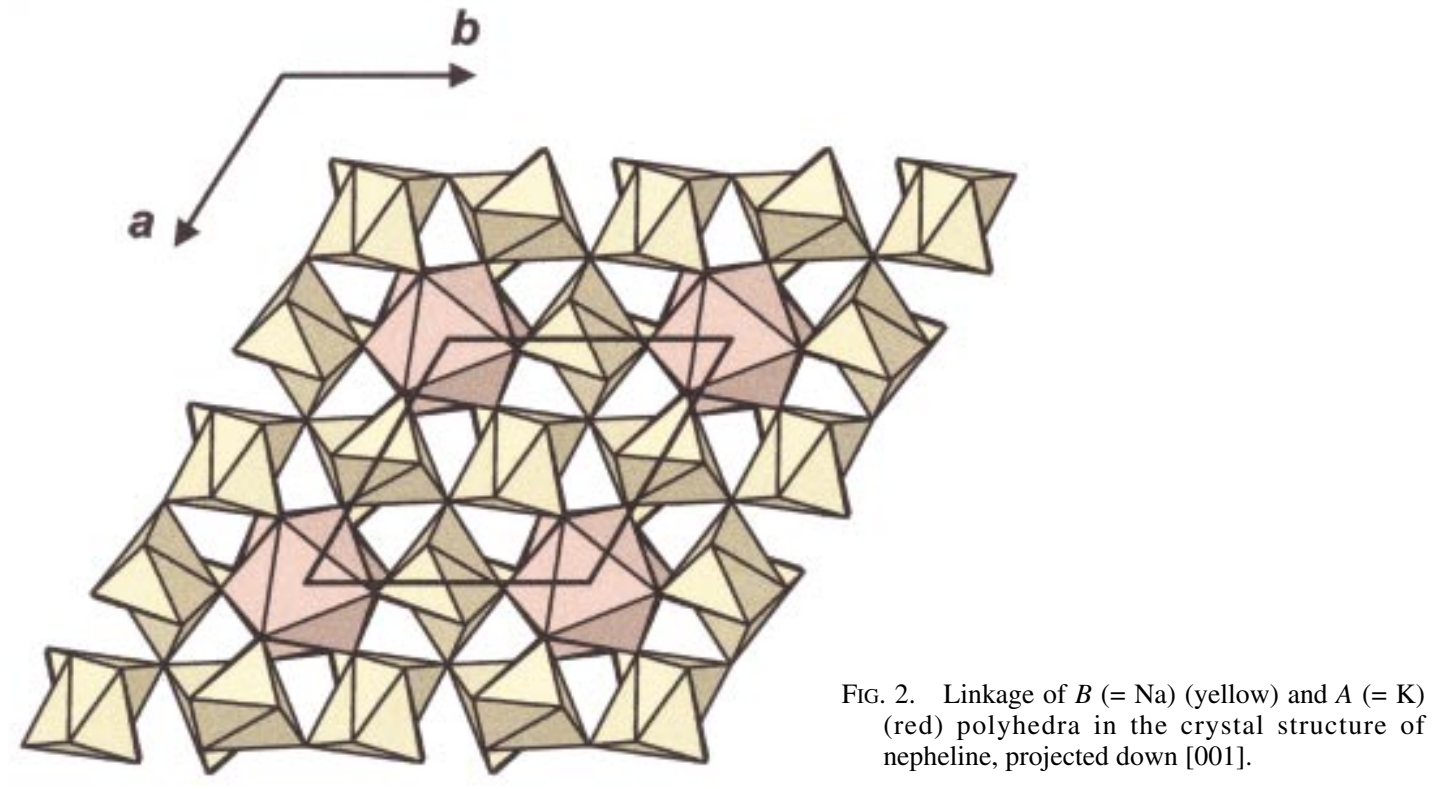

FIG. 2. Linkage of $B(=\mathrm{Na})$ (yellow) and $A(=\mathrm{K})$ nepheline, projected down [001].

TABLE 5. SELECTED INTERATOMIC DISTANCES $(\AA)$ AND ANGLES $\left({ }^{\circ}\right)$ FOR NEPHELINE

\begin{tabular}{|c|c|c|c|c|c|c|c|}
\hline & (1) & (2) & (3) & & (1) & (2) & (3) \\
\hline$B-O(1) a$ & $2.66(4)$ & $2.68(3)$ & $2.62(1)$ & $T(1) \mathrm{j}-\mathrm{O}(1)-T(2)$ & $156.9(8)$ & $156.1(7)$ & $155.2(4)$ \\
\hline$B-O(2) b$ & $2.542(1)$ & $2.531(2)$ & $2.533(1)$ & $T(4) \mathrm{k}-\mathrm{O}(2)-T(3)$ & $137.60(7)$ & $138.22(9)$ & $137.79(6)$ \\
\hline$B-O(3)$ & $2.627(4)$ & $2.620(5)$ & $2.632(3)$ & $T(4) \mid-O(3)-T(2) !$ & $140.5(2)$ & $141.0(2)$ & $140.9(1)$ \\
\hline$B-O(3) c$ & $2.784(3)$ & $2.792(5)$ & $2.788(3)$ & $T(1)-O(4)-T(3)$ & $140.1(2)$ & $140.1(2)$ & $139.8(1)$ \\
\hline$B-O(4) b$ & $2.759(3)$ & $2.756(5)$ & $2.759(3)$ & $T(3)-O(5)-T(4) \mid$ & $140.7(2)$ & $141.6(3)$ & $141.0(1)$ \\
\hline$B-O(4) d$ & $2.591(3)$ & $2.594(5)$ & $2.588(3)$ & $T(3)-O(6)-T(4) m$ & $141.3(2)$ & $141.6(3)$ & $141.5(1)$ \\
\hline$B-O(5)$ & $2.493(2)$ & $2.485(4)$ & $2.490(2)$ & $<T-O-T>$ & 142.9 & 143.1 & 142.69 \\
\hline$B-O(6) d$ & $2.613(3)$ & $\underline{2.595(4)}$ & $2.600(2)$ & & & & \\
\hline \multirow[t]{2}{*}{$<B-O>$} & 2.633 & 2.632 & 2.627 & $O(1) e-T(1)-O(4) b$ & $115.9(9)$ & $117.0(5)$ & $114.8(6)$ \\
\hline & & & & $O(1) e-T(1)-O(4) f$ & $97.4(8)$ & $97.5(7)$ & $96.13(3)$ \\
\hline$A-O(2) \mathrm{e} \quad \times 3$ & $3.026(1)$ & $3.035(1)$ & $3.036(1)$ & $O(1) e-T(1)-O(4)$ & $110.7(1.5)$ & $109.7(1.1)$ & $112.5(8)$ \\
\hline$A-O(5) e \quad \times 3$ & $2.998(2)$ & $3.010(3)$ & $3.005(2)$ & $O(4)-T(1)-O(4) b \times 3$ & $110.7(1)$ & $110.6(2)$ & $110.9(1)$ \\
\hline$A-O(6) f \quad \times 3$ & $\underline{2.972(2)}$ & $2.982(4)$ & $2.983(2)$ & $\langle O-T(1)-O\rangle$ & 108.7 & 108.7 & 108.57 \\
\hline \multirow[t]{2}{*}{$<A-O>$} & 2.999 & 3.009 & 3.008 & & & & \\
\hline & & & & $O(1)-T(2)-O(3) g$ & $117.0(9)$ & $117.9(6)$ & $115.9(7)$ \\
\hline$T(1)-\mathrm{O}(1) \mathrm{e}$ & $1.725(8)$ & $1.73(1)$ & $1.731(6)$ & $O(1)-T(2)-O(3) n$ & $97.1(9)$ & $96.8(7)$ & $95.75(3)$ \\
\hline$T(1)-O(4) \times 3$ & $1.733(2)$ & $1.721(3)$ & $1.732(2)$ & $O(1)-T(2)-O(3) f$ & $110.9(1.6)$ & $109.7(1.2)$ & $113.1(9)$ \\
\hline \multirow[t]{2}{*}{$<T(1)-O>$} & 1.731 & 1.723 & 1.732 & $O(3) g-T(2)-O(3) f \times 3$ & $110.3(1)$ & $110.6(2)$ & $110.4(1)$ \\
\hline & & & & $<\mathrm{O}-\mathrm{T}(2)-\mathrm{O}>$ & 108.8 & 108.8 & 108.8 \\
\hline$T(2)-\mathrm{O}(1)$ & $1.612(7)$ & $1.60(1)$ & $1.614(6)$ & & & & \\
\hline$T(2)-O(3) f \times 3$ & $1.604(2)$ & $1.604(3)$ & $1.602(2)$ & $O(4)-T(3)-O(6)$ & $109.1(1)$ & $108.5(2)$ & $108.4(1)$ \\
\hline \multirow[t]{2}{*}{$<T(2)-\mathrm{O}\rangle$} & 1.606 & 1.603 & 1.605 & $O(5)-T(3)-O(4)$ & $111.7(1)$ & $111.2(2)$ & $111.60(9)$ \\
\hline & & & & $O(2)-T(3)-O(4)$ & $108.9(1)$ & $108.5(2)$ & $108.6(1)$ \\
\hline$T(3)-O(2) \mathrm{h}$ & $1.619(3)$ & $1.620(4)$ & $1.617(2)$ & $O(5)-T(3)-O(6)$ & $109.1(1)$ & $109.5(2)$ & $109.61(9)$ \\
\hline$T(3)-\mathrm{O}(4) \mathrm{g}$ & $1.607(2)$ & $1.613(4)$ & $1.611(2)$ & $O(2)-T(3)-O(6)$ & $110.0(1)$ & $110.5(2)$ & $110.23(8)$ \\
\hline$T(3)-O(5) g$ & $1.619(2)$ & $1.615(3)$ & $1.619(2)$ & $O(2)-T(3)-O(5)$ & $108.1(1)$ & $108.5(2)$ & $108.34(9)$ \\
\hline$T(3)-O(6) i$ & $1.617(2)$ & $1.611(4)$ & $1.616(2)$ & $\langle O-T(3)-O\rangle$ & 109.5 & 109.5 & 109.47 \\
\hline \multirow[t]{2}{*}{$<T(3)-O>$} & 1.616 & 1.615 & 1.616 & & & & \\
\hline & & & & $O(3) g-T(4)-O(5) g$ & $107.3(1)$ & $106.9(2)$ & $107.0(1)$ \\
\hline$T(4)-\mathrm{O}(2) \mathrm{h}$ & $1.738(3)$ & $1.725(4)$ & $1.738(2)$ & $\mathrm{O}(2) \mathrm{h}-T(4)-\mathrm{O}(3) \mathrm{g}$ & $108.1(1)$ & $107.7(2)$ & $107.8(1)$ \\
\hline$T(4)-O(3) \mathrm{g}$ & $1.731(2)$ & $1.724(3)$ & $1.730(2)$ & $O(2) h-T(4)-O(5) g$ & $110.15(9)$ & $110.1(1)$ & $110.20(8)$ \\
\hline$T(4)-\mathrm{O}(5) \mathrm{g}$ & $1.735(2)$ & $1.724(4)$ & $1.734(2)$ & $\mathrm{O}(6) \mathrm{i}-\mathrm{T}(4)-\mathrm{O}(3) \mathrm{g}$ & $113.8(1)$ & $113.2(2)$ & $113.31(9)$ \\
\hline$T(4)-O(6) i$ & $1.739(2)$ & $1.736(3)$ & $1.735(2)$ & $O(6) \mathrm{i}-T(4)-\mathrm{O}(5) \mathrm{g}$ & $109.6(1)$ & $110.6(2)$ & $110.27(8)$ \\
\hline \multirow[t]{2}{*}{$\langle T(4)-O\rangle$} & 1.736 & 1.728 & 1.734 & $O(6) \mathrm{i}-T(4)-O(2) \mathrm{h}$ & $107.9(1)$ & $108.3(2)$ & $108.22(9)$ \\
\hline & & & & $<\mathrm{O}-T(4)-\mathrm{O}>$ & 109.5 & 109.5 & 109.47 \\
\hline
\end{tabular}

a: $2-y, x-y+1, z ; b:-x+y+1,-x+1, z ; \quad$ c: $2-x, 1-y, 1 / 2+z ; d: x-y+1, x, 2+z ;$ e: $1-x, 1-y, z-1 / 2 ; f: 1-y, x-y, z$; g: $x-1, y, z ; \mathrm{h}: x-y, x, z-1 / 2 ;$ i: $1-y, x-y+1, z ; j: 1-x, 1-y, 1 / 2+z ; \quad$ : $y,-x+y, z+1 / 2 ;$ l: $x+1, y, z ; m:-x+y, 1-x, z$

$\mathrm{n}:-x+y+1,-x+2, z$. 
stand the reason for this, it is instructive to compare the relevant bond-lengths in both the ordered [O(1) on axis] and disordered $[\mathrm{O}(1)$ off axis] configurations (Table 8). Examination of the bonds involving $\mathrm{O}(1)$ shows that the disordered (final) configuration has longer $\mathrm{O}(1)-T$ distances (by $\sim 0.035 \AA$ ) and a much shorter $\mathrm{O}(1)-\mathrm{Na}$ distance (by $0.293 \AA$ ). Fortunately, the other bonds involving these cations are not significantly different in the ordered and disordered models, and hence we can focus just on the effect of the difference in bond-lengths shown in Table 8. There are three significant issues here: (1) differences in T-O bond-lengths, (2) the difference in the $\mathrm{Na}-\mathrm{O}(1)$ bond-lengths, (3) the difference in $\mathrm{T}$ $\mathrm{O}-T$ angle.

(1) In the ordered model, the $\langle T-\mathrm{O}>$ distances are not in accord with the (Al, Si) content. In particular, the $<T(2)-\mathrm{O}>$ distance of $1.596 \AA$ is too short, even for a tetrahedron occupied solely by $\mathrm{Si}$. Thus it is apparent that the disorder is necessary for the tetrahedra to adopt bond lengths in accord with their site-occupancies.

TABLE 6. BOND-VALENCE* TABLE $(v u)$ FOR NEPHELINE

\begin{tabular}{|c|c|c|c|c|c|c|c|}
\hline \multicolumn{8}{|c|}{ (1) } \\
\hline & $T(1)$ & $T(2)$ & $T(3)$ & $T(4)$ & $A(\approx \mathrm{K})$ & $B(=\mathrm{Na})$ & $\Sigma$ \\
\hline$O(1)$ & 0.81 & 1.05 & & & & 0.10 & 1.96 \\
\hline $\mathrm{O}(2)$ & & & 1.03 & 0.78 & $0.07^{\times 3} \downarrow$ & 0.14 & 2.02 \\
\hline \multirow[t]{2}{*}{$O(3)$} & & $1.07^{\times 3} !$ & & 0.88 & & 0.11 & 2.14 \\
\hline & & & & & & 0.08 & \\
\hline \multirow[t]{2}{*}{$O(4)$} & $0.80^{\times 3} \downarrow$ & & 1.07 & & & 0.08 & 2.07 \\
\hline & & & & & & 0.12 & \\
\hline$O(5)$ & & & 1.03 & 0.78 & $0.08^{\times 3} \downarrow$ & 0.15 & 2.04 \\
\hline $\mathrm{O}(6)$ & & & 1.04 & 0.78 & $0.09^{\times 3} \downarrow$ & 0.11 & 2.02 \\
\hline$\underline{\Sigma}$ & 3.24 & 4.26 & 4.17 & 3.22 & 0.72 & 0.89 & \\
\hline \multicolumn{8}{|c|}{ (2) } \\
\hline & $T(1)$ & $T(2)$ & $T(3)$ & $T(4)$ & $A(\approx \mathrm{K})$ & $B(=\mathrm{Na})$ & $\Sigma$ \\
\hline$O(1)$ & 0.79 & 1.09 & & & & 0.10 & 1.98 \\
\hline $\mathrm{O}(2)$ & & & 1.03 & 0.81 & $0.06^{\times 3} \downarrow$ & 0.14 & 2.05 \\
\hline \multirow[t]{2}{*}{$\mathrm{O}(3)$} & & $1.07^{\times 3} \downarrow$ & & 0.81 & & 0.11 & 2.07 \\
\hline & & & & & & 0.08 & \\
\hline \multirow[t]{2}{*}{$O(4)$} & $0.81^{\times 3} \downarrow$ & & 1.05 & & & 0.08 & 2.06 \\
\hline & & & & & & 0.12 & \\
\hline$O(5)$ & & & 1.04 & 0.81 & $0.07^{\times 3}$ & 0.15 & 2.08 \\
\hline $\mathrm{O}(6)$ & & & 1.05 & 0.78 & $0.07^{\times 3} \downarrow$ & 0.12 & 2.03 \\
\hline$\Sigma$ & 3.22 & 4.30 & 4.17 & 3.21 & 0.60 & 0.90 & \\
\hline \multicolumn{8}{|c|}{ (3) } \\
\hline & $T(1)$ & $T(2)$ & $T(3)$ & $T(4)$ & $A(\approx \mathrm{K})$ & $B(=\mathrm{Na})$ & $\Sigma$ \\
\hline $\mathrm{O}(1)$ & 0.80 & 1.05 & & & & 0.11 & 1.96 \\
\hline $\mathrm{O}(2)$ & & & 1.04 & 0.78 & $0.07^{\times 3} !$ & 0.14 & 2.03 \\
\hline \multirow[t]{2}{*}{$\mathrm{O}(3)$} & & $1.08^{\times 3} \downarrow$ & & 0.80 & & 0.11 & 2.07 \\
\hline & & & & & & 0.08 & \\
\hline \multirow[t]{2}{*}{$O(4)$} & $0.79^{\times 3} \downarrow$ & & 1.05 & & & 0.08 & 2.04 \\
\hline & & & & & & 0.12 & \\
\hline$O(5)$ & & & 1.03 & 0.79 & $0.08^{\times 3} \downarrow$ & 0.15 & 2.05 \\
\hline $\mathrm{O}(6)$ & & & 1.04 & 0.79 & $0.08^{\times 3} \downarrow$ & 0.12 & 2.03 \\
\hline$\Sigma$ & 3.17 & 4.29 & 4.16 & 3.16 & 0.69 & 0.91 & \\
\hline
\end{tabular}

${ }^{*}$ Calculated from the parameters of Brown (1981)
(2) The $\mathrm{O}(1)$ site is surrounded by three $B$ sites at a (non-bonding) distance of 2.949(1) A (Table 8) in the ordered model, and the coordination number of the $B$ site is [7]. Where the $\mathrm{O}(1)$ site is disordered off the symmetry axis, it has moved sufficiently close to one $B$ site $(2.66 \AA)$ to change its coordination number to [8]; the other two locally associated $B$ sites are too far from the off-axis of the $\mathrm{O}(1)$ site to bond to its constituent cation (Table 8) and retain a coordination number of [7]. Thus in the overall structure, one third of the $B$ sites have a coordination number of [8] and two thirds of the $B$ sites have a coordination number of [7]. We cannot argue that this change is driven by bond-valence requirements of the $\mathrm{O}(1)$ or $B$-site atoms, as the valence-sum rule usually contains too much noise to discern significance in the presence or absence of such very weak bonds.

(3) In the ordered model, the $T(1)-\mathrm{O}(1)-T(2)$ angle is $180^{\circ}$; such angles are well known to be energetically unfavorable in aluminosilicate frameworks. In the disordered model, the $T(1)-\mathrm{O}(1)-T(2)$ angle has relaxed to $\sim 157^{\circ}$ (Table 8 ), significantly reducing strain within the framework.

In summary, all three features (size of tetrahedra, $\mathrm{Na}$ coordination number, and reduction of $T-\mathrm{O}-T$ strain) suggest that the disordered model is energetically more favorable than the ordered model, and the driving force for the disordered configuration may involve all three of these features.

TABLE 7. SITE POPULATIONS OF THE $A, B$ - AND T-SITES IN NEPHELINE SAMPLES (1-3)

\begin{tabular}{|c|c|c|c|}
\hline & (1) & (2) & (3) \\
\hline$T(1)$ & $1.96 \mathrm{Al}^{*}+0.04 \mathrm{Si}$ & $1.87 \mathrm{Al}+0.13 \mathrm{Si}$ & $1.97 \mathrm{Al}^{\star \star}+0.03 \mathrm{Si}$ \\
\hline$T(2)$ & $2.00 \mathrm{Si}$ & $2.00 \mathrm{Si}$ & $2.00 \mathrm{Si}$ \\
\hline$T(3)$ & $6.00 \mathrm{Si}$ & $6.00 \mathrm{Si}$ & $6.00 \mathrm{Si}$ \\
\hline$T(4)$ & $5.87 \mathrm{Al}^{*}+0.13 \mathrm{Si}$ & $5.62 \mathrm{Al}+0.38 \mathrm{Si}$ & $5.91 \mathrm{Al}^{* *}+0.09 \mathrm{Si}$ \\
\hline$A$ & $1.91 \mathrm{~K}+0.09 \square$ & $1.60 \mathrm{~K}+0.40 \square$ & $1.76 \mathrm{~K}+0.24 \square$ \\
\hline$B$ & $6.00 \mathrm{Na}$ & $6.00 \mathrm{Na}$ & $5.86 \mathrm{Na}+0.13 \mathrm{Ca}$ \\
\hline
\end{tabular}

* includes $0.05 \mathrm{Fe}^{3+}$; ** includes $0.02 \mathrm{Fe}^{3+}$.

TABLE 8. SELECTED BOND-LENGTHS (§̊) AND BOND-ANGLES $\left(^{\circ}\right.$ INVOLVING O(1) FOR ORDERED AND DISORDERED MODELS OF THE STRUCTURE OF NEPHELINE (1)

\begin{tabular}{|c|c|c|c|c|c|}
\hline & On axis & Disordered & & On axis & Disordered \\
\hline$O(1)-T(1)$ & $1.699(8)$ & $1.725(8)$ & $T(1)-\mathrm{O}(1)$ & $1.699(8)$ & $1.725(8)$ \\
\hline$O(1)-T(2)$ & $1.571(8)$ & $1.612(8)$ & $T(1)-O(4) \times 3$ & $1.733(2)$ & $1.733(2)$ \\
\hline $\mathrm{O}(1)-\mathrm{Na}$ & $2.949(1)$ & $2.66(4)$ & $\langle T(1)-0\rangle$ & 1.725 & 1.731 \\
\hline $\mathrm{O}(1)-\mathrm{Na}$ & $2.949(1)$ & 2.97(5) & & & \\
\hline \multirow[t]{4}{*}{$\mathrm{O}(1)-\mathrm{Na}$} & $2.949(1)$ & $3.24(1)$ & $T(2)-O(1)$ & $1.571(8)$ & $1.612(8)$ \\
\hline & & & $T(2)-O(3) \times 3$ & $1.604(2)$ & $1.604(2)$ \\
\hline & & & $\langle T(2)-\mathrm{O}\rangle$ & 1.596 & 1.606 \\
\hline & & & $T(1)-O(1)-T(2)$ & 180 & $156.9(8)$ \\
\hline
\end{tabular}




\section{PARAGENESIS}

According to Dollase \& Peacor (1971), Al-Si disorder in nepheline increases with increasing temperature of equilibration. The end-member nepheline from pegmatites of the Khibina-Lovozero complex occurs in a very low-temperature environment relative to most parageneses of nepheline, and this paragenesis is in accord with the maximal degree of order observed in this sample: (1) $\mathrm{K}-\square$ at the interstitial $A$ site, and (2) Al-Si at the framework $T$ sites. Such maximal order is characteristic of several of the minerals in this paragenesis. At most localities (e.g., Lovozero, Ilímaussaq, Mont SaintHilaire), crystallization of agpaitic alkaline magma is characterized by consumption of $\mathrm{K}$ to form $\mathrm{K}$-feldspar (mostly) and nepheline, while Na progressively accumulates in residual melts, producing Na-rich minerals in late-stage and post-magmatic differentiates. The situation at Mount Koashva (and elsewhere in the Khibina central arc) is somewhat different. Substantial K survived crystallization of the primary rocks and produced exotic perpotassic mineralization in late-stage pegmatites and hydrothermal veins. As noted by Khomyakov (1998), several minerals in these late-stage hyperagpaitic rocks have highly ordered crystal structures. Minerals such as megacyclite, $\mathrm{Na}_{16} \mathrm{~K}_{2}\left[\mathrm{Si}_{18} \mathrm{O}_{36}(\mathrm{OH})_{18}\right]$ $\left(\mathrm{H}_{2} \mathrm{O}\right)_{38}$ (Yamnova et al. 1992, Khomyakov et al. 1993) and malinkoite, $\mathrm{Na}$ [B Si O $\mathrm{S}_{4}$ ] (Khomyakov et al. 2000, Sokolova et al. 2001) are unique chemical compositions. Other minerals are highly ordered polymorphs of more commonly disordered structures: megakalsilite, $\mathrm{K}$ [Al $\mathrm{Si} \mathrm{O}_{4}$ ] (Khomyakov et al. 2002) is a highly ordered

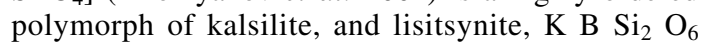
(Khomyakov et al. 2000, Sokolova et al. 2001) is a highly ordered polymorph of synthetic $\mathrm{K} \mathrm{B} \mathrm{Si}_{2} \mathrm{O}_{6}$, which has the leucite structure.

\section{Long-RAnge Al-Si Order In NePheline}

The nepheline crystals examined here are from both low-temperature and high-temperature environments, and yet all crystals show the maximum degree of $\mathrm{Al}-\mathrm{Si}$ order consonant with their bulk composition. This result is in accord with the ordered character reported for synthetic nepheline by Gregorkiewitz (1984). It is also in accord with the ordered character reported for nepheline from different parageneses by MAS NMR (e.g., Stebbins et al. 1986, who examined samples from Bancroft, Ontario, and Monte Somma, Italy). However, our results contrast with previous crystal-structure work on nepheline (see Table 1 for details), work that includes samples from two of the three localities examined here. The origin of the differences in the structure-refinement results is not clear. However, what is clear is that nepheline does seem to exhibit maximal Al-Si order consonant with the bulk composition of the crystal.

\section{ACKNOWLEDGEMENTS}

We thank Petr Černý for the nepheline sample from Bancroft, Ontario, Canada, Giancarlo Della Ventura for the nepheline sample from Monte Somma, Italy, and Mark Cooper for his help with collection of the X-ray data. This paper was materially improved by the comments of Petra Cimoncic and Claes C. Christiansen, and the editorial work of Ole Johnsen and Robert F. Martin. This work was supported by a Canada Research Chair and Major Equipment, Research and Major-Facilities Access grants to FCH from the Natural Sciences and Engineering Research Council of Canada.

\section{REFERENCES}

BRown, I.D. (1981): The bond-valence method: an empirical approach to crystal structure and bonding. In Structure and Bonding in Crystals II (M. O'Keeffe and A. Navrotsky, eds.). Academic Press, New York, N.Y. (1-30).

Buerger, M.J., Klein, G.E. \& Donnay, G. (1954): Determination of the crystal structure of nepheline. Am. Mineral. 39, $805-818$.

Dollase, W.A. (1970): Least-squares refinement of the structure of a plutonic nepheline. Z. Kristallogr. 132, 27-44.

\& PEACOR, D.R. (1971): Si-Al ordering in nephelines. Contrib. Mineral. Petrol. 30, 129-134.

\& Thomas, V.M. (1978): The crystal chemistry of silica-rich, alkali-deficient nepheline. Contrib. Mineral. Petrol. 66, 311-318.

Foreman, N. \& Peacor, D.R. (1970): Refinement of the nepheline structure at several temperatures. Z. Kristallogr. 132, 45-70.

GREGORKIEWITZ, M. (1984): Crystal structure and Al/Si-ordering of a synthetic nepheline. Bull. Minéral. 107, 499-507.

International Tables for X-ray Crystallography (1992): Kluwer Academic Publishers, Dordrecht, The Netherlands.

HAHN, T. \& BuERGER, M.J. (1955): The detailed structure of nepheline, $\mathrm{KNa}_{3} \mathrm{Al}_{4} \mathrm{Si}_{4} \mathrm{O}_{16}$. Z. Kristallogr. 106, 308-338.

Kномүакоv, A.P. (1998): Mineralogy of hyperalkaline rocks: advances and prospects. Int. Mineral. Assoc., $17^{\text {th }}$ Gen. Meet. (Toronto), Programme and Abstr., A108.

Nechelyustov, G.N., Sokolova, E.V., BonacCORSI, E., MERLINO, S \& PASERO, M. (2002): Megakalsilite, a new polymorph of $\mathrm{KAlSiO}_{4}$ from the Khibina alkaline massif, Kola Peninsula, Russia: mineral description and crystal structure. Can. Mineral. 40, 961-970.

\& HAWTHORNE, F.C. (2000): New borosilicates: malinkoite, $\mathrm{NaBSiO}_{4}$, and lisitsynite, $\mathrm{KBSi}_{2} \mathrm{O}_{6}$, from alkaline pegmatites of the Khibina- 
Lovozero complex, Kola Peninsula. Zap. Vser. Mineral. Obshchest. 129(6), 35-42 (in Russ.).

, Yamnova, N.A. \& Pushcharovsky, D.Yu. (1993): Megacyclite, $\mathrm{Na}_{8} \mathrm{KSi}_{9} \mathrm{O}_{18}(\mathrm{OH})_{9} \bullet 19 \mathrm{H}_{2} \mathrm{O}$, a new mineral. Zap. Vser. Mineral. Obshchest. 122(1), 125128 (in Russ.).

Kroll, H. \& RibBE, P.H. (1983): Lattice parameters, composition, and Al,Si order in alkali feldspars. In Feldspar Mineralogy (P.H. Ribbe, ed.). Rev. Mineral. 2, 57-99.

MCConNell, J.D.C. (1962): Electron-diffraction study of subsidiary maxima of scattered intensity in nepheline. Mineral. Mag. 33, 114-124.

Merlino, S. (1984): Feldspathoids: their average and real structures. In Feldspars and Feldspathoids. Structures, Properties and Occurrences (W.L. Brown, ed.). NATO Adv. Study Inst., Ser. C: Mathematical and Physical Sci. 137, 435-470. D. Reidel, Dordrecht, The Netherlands.

PARKER, J.M. (1972): The domain structure of nepheline. $Z$. Kristallogr. 136, 255-272.

\& MCConNELL, J.D.C. (1971): Transformation behaviour in the mineral nepheline. Nature (Phys. Sci.) 234, 178-179.

Sahama, T.G. (1958): A complex form of natural nepheline from Iivaara, Finland. Am. Mineral. 43, 165-166.

(1962): Order-disorder in natural nepheline solid solutions. J. Petrol. 3, 65-81.

SHANNON, R.D. (1976): Revised effective ionic radii and systematic studies of interatomic distances in halides and chalcogenides. Acta Crystallogr. A32, 751-767.
SHELDRICK, G.M. (1997): SHELXL97, Program for the Solution and Refinement of Crystal Structures. Univ. of Göttingen, Göttingen, Germany.

Simmons, W.B., JR. \& Peacor, D.R. (1972): Refinement of the crystal structure of a volcanic nepheline. Am. Mineral. 57, 1711-1719.

Sokolova, E.V., Hawthorne, F.C. \& Khomyakov, A.P. (2001): The crystal chemistry of malinkoite $\mathrm{NaBSiO}_{4}$, and lisitsynite, $\mathrm{KBSi}_{2} \mathrm{O}_{6}$, from the Khibina-Lovozero complex, Kola Peninsula, Russia. Can. Mineral. 39, 159-169.

Stebbins, J.F., Murdoch, J.B., Carmichael, I.S.E. \& Pines, A. (1986): Defects and short-range order in nepheline group minerals: a silicon-29 nuclear magnetic resonance study. Phys. Chem. Minerals 13, 371-381.

TILlEy, C.E. (1954): Nepheline - alkali feldspar paragenesis. Am. J. Sci. 252, 65-75.

Wainwright, J.E. \& Starkey, J. (1971): A refinement of the structure of anorthite. Z. Kristallogr. 133, 75-84.

Yamnova, N.A., Rastsvetaeva, R.K., Pushcharovsky, D.Yu., Menraf, T., Mikheeva, M.G. \& Khomyakov, A.P. (1992): Crystal structure of a new ring Na,K-silicate $\mathrm{Na}_{16} \mathrm{~K}_{2}\left[\mathrm{Si}_{8} \mathrm{O}_{36}(\mathrm{OH})_{18}\right] \cdot 38 \mathrm{H}_{2} \mathrm{O}$. Kristallografiya 37, 334344 (in Russ.).

Received October 14, 2001, revised manuscript accepted November 23, 2002. 